\title{
Regional Disparities of the Voluntary Pension- Insurance Market in Serbia
}

\author{
Emilija MaNić and Tatjana RaKonJAC ANTIĆ, both Belgrade [Beograd]*
}

with 5 figures and 3 tables in the text

\section{Content}

Summary 175

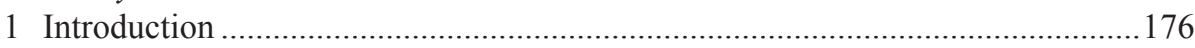

2 The voluntary pension insurance in the EU: some examples................................ 178

3 Characteristics of voluntary pension insurance in Serbia ................................... 180

4 Regional disparities of the voluntary pension-insurance market ...........................182

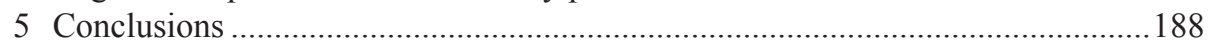

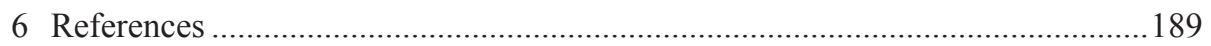

\section{Summary}

The system of voluntary pension insurance should enable the achievement of greater security of individuals and their families in the older age. Individual responsibility is developed through the system of voluntary pension-insurance, but this system also strengthens the pension insurance as an economic category. The voluntary pension insurance is at the beginning of its development in Serbia, with a small number of insured persons, and it represents an additional form of achieving pensions for participants. Further development of this system is very important for the insurance industry in Serbia but also for the development of the national economy.

This paper aims to revail the regional disparities of the voluntary pensioninsurance market in Serbia, considering the existing regional differences of its main factors. The interrelations between those factors were analysed using geographical

* Emilija Manić, Prof. Associate, PhD., Tatjana RakonjaC-Antić, Prof. PhD., University of Belgrade, Faculty of Economics, Kamenicka 6, SR-110000 Belgrade, Serbia; email: geografija@, ekof.bg.ac.rs; rakonjacantic@ekof.bg.ac.rs 
information system (GIS) analysis. The GIS is used to identify certain patterns in the spatial distribution of the main elements and factor, as well as the voluntary pensioninsurance market, visualising possible directions of voluntary pension-insurance growth through different regions in the country.

\section{Introduction}

The primary goal of an adequately defined system of voluntary pension insurance (VPI) is to increase the amount of remuneration (pension) for the participants, and in most cases, it is a supplement to the system of mandatory pension insurance. In Serbia, voluntary pension insurance is at its beginnings. The adoption of the Law on Voluntary Pension Funds and Pension Plans at the end of 2005 (with the implementation of certain provisions as of March/April 2006), officially marked the start of the implementation of the voluntary pension-insurance system in Serbia. Several years before the adoption of this law, VPI services were offered by a small number of insurers on our insurance market. (Insurance companies conducted their business in accordance with the provisions of the Law on Insurance.) The activities in this system of pension insurance are carried out in four voluntary pension funds (VPF) with a small number of insured and an even smaller number of beneficiaries of pension insurance. Besides the problem of insufficient development or high market concentration on the VPI market, Serbia is also characterised by the existence of substantial regional differences.

In order to efficiently define the pension insurance, at the end of the last century, the World Bank proposed a model that contained three levels (pillars) of pension insurance (Kočović, ŠulejIĆ \& RAKONJAC-AnTIĆ 2010). The first level (pillar) includes mandatory pension insurance, which operates as a 'pay as you go' funding system. The second level (pillar) is called mandatory supplementary pension and disability insurance as a 'fully funded' system, while the third level (pillar) is voluntary pension insurance. In Serbia, since the adoption of the Law on Voluntary Pension Funds and Pension Plans in 2005, in addition to the mandatory pension and disability insurance (which is not economically self-sustaining) there has also been voluntary pension insurance in place, which is a form of savings and a source, in most cases, of additional pension remuneration for individuals participating in this system. This system of pension-insurance functions on a voluntary basis, and each participant has their own individual account to which the payment of contributions that are invested are accounted, and profits are attributed periodically. The amount of pension remuneration depends on the amount of paid contributions and the yield earned on invested funds from contributions (KoČović, RAKONJAC-ANTIĆ \& Jovović 2011). Using the 'fully funded' system pension insurance requires the proper functioning of financial markets, on which the accumulated funds can be invested in various forms of assets (RAKONJACANTIĆ 2012). The Law on Voluntary Pension Funds and Pension Plans governs the 
structure and elements of the system, i.e. their interconnections and relations (voluntary pension funds of voluntary pension funds management companies, custodian banks, the relationship with the National Bank of Serbia [NBS] in exercising supervision over the activities of voluntary pension funds management companies and other issues of importance for this area) (Law on Voluntary Pension Funds and Pension Plans, 85/2005 and 31/2011).

In May 2011, Serbia adopted amendments to the Law on Voluntary Pension Funds and Pension Plans, with a view of a higher level of protection for the members of voluntary pension funds, as well as of improving the business environment for voluntary pension funds (www.nbs.rs). The minimum age limit for withdrawal in the form of pension remuneration (pension) was increased from former 53 years to 58 years of age. A one-time withdrawal of funds amounting up to $30 \%$ of the accumulated funds was granted. ${ }^{1}$ It also allowed for depositing a higher amount of assets in banks and investments in short-term securities issued or guaranteed by the bank. When buying the first apartment, the funds in the voluntary pension fund can be used as a guarantee for the fulfillment of the obligations of the voluntary pension fund member towards the state and banks etc.

Although the VPI market in Serbia practically began to function with the adoption of the legal frameworks ten years ago, measured in European and global standards, it is undeveloped. There are objective and subjective factors contributing to this fact arising from the general state of the Serbian economy and market trends of financial capital in Serbia and abroad. An expected pension system reform in the mid-past decade in Serbia failed to occur, which rapidly reduced the number of newly formed voluntary pension funds management companies, and those that have remained, have continued to work in much less favourable conditions. (The third pillar of pension insurance has not been established, and the global economic crisis has had a negative impact on the financial market in Serbia.) In such circumstances the struggle for potential insurants is hard. This is especially important if we bear in mind the fact that Serbia is a country with large regional differences in terms of its economic and social development. Therefore, different methodologies have been used in order to identify 'unsaturated' parts of the market, among which the best results are produced by those based on regional market analysis, i.e. the factors that shape the market. With this respect, a common and successfully used system is the geographic information system (GIS).

GIS is an information system for collecting, storing, analysing and displaying spatial (geographic) data (Longley, Goodchild, MAguiRe \& RHInd 2005). In the context of voluntary pension-insurance market, GIS is primarily used as a technique/tool for the analysis of the market, i.e. the analysis of the existing and potential insured and voluntary pension-insurance beneficiaries (FrANCICA 1994, 1993; MANIĆ 2010). Besides that enables linking data to a specific location ( $\mathrm{x}$, y coordinates), another advantage of GIS is reflected in the fact that by attaching attributes, spatial relationships and 1 These changes do not affect the already existing participants in voluntary pension insurance. 
temporal dynamics of the location of a particular object, phenomenon or process, it transforms geographic data into geographic information. Information has become a key factor for the adoption of good quality decisions, that is, a factor influencing the reduction in the risk of errors in the decision-making process.

Within the GIS analysis, it is possible to perform simple analyses, such as data transformation and measurement, then standard statistical analyses, and optimisation of complex processes and modeling. In the field of voluntary pension insurance, GIS is primarily used in the analysis of the current market, and at different levels (spatial units). Using the data on the existing insured or beneficiaries of voluntary pension insurance as well as the data on the population of a certain area, it is possible to quickly and efficiently identify the locations of potentially insured persons.

However, there are significant limitations in the application of GIS in the field of voluntary pension insurance. The most obvious problem is the lack of data. As the experience so far has shown, the introduction of GIS or the implementation of a GIS project, in financial terms, involves high costs, about $80 \%$ of which goes to the data (Longley \& GRAham 1995). The problem with the lack of data is not only typical for our country, but it is rather a universal limitation, especially in the countries with modest statistical monitoring of certain areas. For Serbia, and the neighbouring countries as well, another limiting factor is particularly prominent. It is the degree of development of the GIS itself and its penetration into the field of business management and economics. Awareness of the opportunities that GIS provides in different spheres of economy and business is very poor (MANIĆ 2010).

\section{The voluntary pension insurance in the $\mathrm{EU}$ : some examples}

Voluntary pension insurance in the European Union (EU) is represented through individual pension insurance and pension insurance provided by employers. The contribution funds, in many cases, enjoy favourable tax treatment. Voluntary pension insurance, which is achieved through the so-called third pillar, exists in different modalities and levels of development (It often supplements the mandatory pensioninsurance system.) in Germany, Italy, Poland, Romania, the Netherlands, Croatia and so on.

For example, in 2008 , in Italy, approximately $20.7 \%$ of the employees participated in some of the private pension plans. The assets of the Italian pension funds were worth $4.57 \%$ of GDP. Approximately $4.18 \%$ related to professional private pension plans (provided by the employer), and $0.39 \%$ to individual pension plans. About $6.9 \%$ of total pension income is realised through voluntary pension funds (LE BLANC 2011). In Poland, in 2009, approximately $5 \%$ of the employees participated in the voluntary 
pension insurance (EichHorst, Gerard, Kendzia, Mayrhuber, Nielsen, Runstler \& URL 2011). In 2012, around 0.3 million people participated in voluntary pension insurance in Romania through individual pension insurance within eleven pension funds. Net assets of the funds amounted to 135.24 million Euro. In Germany, about 50\% of the employees are covered by pension plans provided by employers. Contributions are subject to favourable tax treatment. For example, in 2009, contributions of up to 2,500 Euros were not taxed. Approximately $5.3 \%$ of total pension income is realised through voluntary pension insurance. In the Netherlands, about $11.7 \%$ of pension income is realised through the insurance system (LE BLANC 2011).

Following the reform of the pension-insurance system in Croatia, other mandatory pension insurance based on the principle of capitalisation and the third pillar (voluntary pension insurance based on the principle of capitalisation) pensioninsurance types appeared, as of 2002. Four volunteer pension funds management companies started operating in Croatia and manage the assets of both open and closed pension funds. Open pension funds are intended for all citizens residing in Croatia, without any restrictions regarding age or employment. Closed voluntary pension funds are relevant for those employees whose employers are the founders of the fund, or are members of the association that has founded the fund for its members. In 2014, there were six open voluntary pension funds and 16 closed-end voluntary pension funds in the voluntary pension-insurance market (www.hanfa.hr). At the end of 2014 (see Table 1) around 244,000 insured participated in the context of open and closed voluntary pension funds. Net assets of mandatory pension funds amounted to 3.46 billion HRK (Croatian Kuna), i.e. about 412 million Euros.

Table 1: Voluntary pension insurance in Croatia (11/2014)

\begin{tabular}{|l|r|r|r|}
\hline \multicolumn{1}{|c|}{$\begin{array}{c}\text { Type of pension funds/Basic } \\
\text { information }\end{array}$} & $\begin{array}{r}\text { Number } \\
\text { of funds }\end{array}$ & $\begin{array}{c}\text { Number of } \\
\text { participants }\end{array}$ & $\begin{array}{c}\text { Net assets } \\
\text { (in 000 Kunas) }\end{array}$ \\
\hline Open voluntary pension funds & 6 & 219,622 & $2,581,915$ \\
\hline Closed voluntary pension funds & 16 & 23,868 & 580,673 \\
\hline Total: & $\mathbf{2 2}$ & $\mathbf{2 4 3 , 4 9 0}$ & $\mathbf{3 , 4 6 2 , 5 8 8}$ \\
\hline
\end{tabular}

Source: Hrvatska Agencija za Nadzor Financisskih Usluga

There are three advantages with investment: tax relief, government incentives and return on investment for the funds. Payments by employers of up to 6,000 Kuna per year are considered operating costs. On the other hand, saving in voluntary pension funds entitles the participants to government incentives amounting to $15 \%$ of the contributions paid in the previous calendar year, up to 750 Kuna per year. 


\section{Characteristics of voluntary pension insurance in Serbia}

According to the NBS report, in the first quarter of 2014, there were four voluntary pension funds ("Delta Generali"2," "Raiffeisen Future", "DDOR-Garant", and "Dunav") on the Serbian voluntary pension-insurance funds market, which still manage the assets of six pension funds ("DDOR-Garant" and "Delta generali" manage assets of two pension funds), one custody bank ${ }^{3}$ and four intermediary banks. ${ }^{4}$

Table 2: Basic development indicators of the Serbian voluntary pension system

\begin{tabular}{|l|r|r|r|r|r|r|r|r|}
\hline \multicolumn{1}{|c|}{ Year } & 2007 & 2008 & 2009 & 2010 & 2011 & 2012 & 2013 & $\begin{array}{c}\text { First } \\
\text { quarter } \\
\text { of 2014 }\end{array}$ \\
\hline $\begin{array}{l}\text { Management } \\
\text { companies }\end{array}$ & 7 & 9 & 9 & 6 & 6 & 5 & 4 & 4 \\
\hline $\begin{array}{l}\text { Voluntary } \\
\text { pension funds }\end{array}$ & 7 & 10 & 10 & 8 & 9 & 9 & 6 & 6 \\
\hline $\begin{array}{l}\text { Number of } \\
\text { empolyees in } \\
\text { VPFs }\end{array}$ & 196 & 218 & 175 & 129 & 148 & 152 & 126 & 128 \\
\hline $\begin{array}{l}\text { Number of } \\
\text { participiants }\end{array}$ & - & 155,954 & 165,224 & 166,780 & 174,868 & 179,823 & 183,508 & 185,793 \\
\hline $\begin{array}{l}\text { Number of } \\
\text { contracts }\end{array}$ & 158,461 & 201,600 & 215,704 & 220,451 & 234,405 & 240,369 & 244,462 & 250,353 \\
\hline
\end{tabular}

Source: The NBS reports on the voluntary pension funds sector in Serbia for Q4 2007, 2008, 2009, 2010, 2011, 2012, 2013, and Q1 of 2014

In the first quarter of 2014, as compared to 2008 and 2009, there was a decrease in the number of voluntary pension funds (Table 2). The expectations for 2008 and 2009 were the introduction of the second pillar (second level) of pension insurance, a mandatory insurance that would operate on the principle of capitalisation and therefore a larger number of companies appeared, for the purpose of their timely market positioning. Since the implementation of the second pillar of the pension insurance did not happen, and since the number of the insured slowly increased, that number of companies could not survive on the market, so that, as already mentioned above, in the first quarter of 2014 only four management companies operated on the voluntary

\footnotetext{
2 On 16 May 2014, they changed their name into „Generali“ (www.penzijskifond.rs)

„Societe Generale banka Srbije“

4 „NLB banka a.d. Beograd“, „Raiffeisen banka a.d. Beograd“, „Sberbank a.d. Beograd“ and „Societe Generale banka Srbija a.d. Beograd“
} 
pension-insurance market. In the first quarter of 2014, net assets of pension funds amounted to 20.6 billion Dinars, and at the end of 2013, net assets amounted to 19.7 billion Dinars. In 2013, in comparison to the year 2012, there was an increase in net assets of 3.7 billion Dinars (Table 3). This increase occurred mainly due to higher net payments of contributions ( 2.6 billion) in relation to payments ( 0.9 billion) and the profits, which the funds generated from investments (2.0 billion Dinars). In total fund assets, the largest share belongs to the government debt securities.

Table 3: Net assets of voluntary pension funds (in billion RSD)

\begin{tabular}{|c|r|r|r|r|r|r|r|r|}
\hline Year & \multicolumn{1}{|c|}{2007} & \multicolumn{1}{c|}{2008} & \multicolumn{1}{c|}{2009} & \multicolumn{1}{c|}{2010} & \multicolumn{1}{c|}{2011} & \multicolumn{1}{c|}{2012} & \multicolumn{1}{c|}{2013} & \multicolumn{1}{c|}{2014} \\
\hline Net assets & 3.1 & 4.6 & 7.2 & 9.9 & 12.5 & 16.0 & 19.7 & 20.6 \\
\hline
\end{tabular}

Source: The NBS reports on the voluntary pension funds sector in Serbia for 2007, 2008, 2009, 2010, 2011, 2012, 2013, and 2014

The number of insured in the first quarter of 2014 came to 185,508 , which is about $2.5 \%$ of the total population, i.e. one in ten employees is a participant in the voluntary pension insurance. There was no significant increase in the number of insured compared to 2008 (Table 2). Market concentration was high, and the largest fund owned $42 \%$ of the net assets of the sector. The structure of the insured was such that it was dominated by men $(60 \%)$, while the average age of the insured was 45 years.

One of the best ways to show the VPF level of market development is the calculation of the Herfindahl-Hirschman index (HHI). This is a commonly accepted measure of market concentration and it is calculated by squaring the market share of each company competing on the market, and then summing the resulting numbers.

$$
H H I=\sum_{i=1}^{n} s_{i}^{2}
$$

$s_{i}$ - market share of the management company of VPF, $n$ - number of VPF

The HHI number can range from close to zero to 10,000 . The closer a market is to being a monopoly, the higher the market's concentration (and the lower its competition). If, for example, there were only one company in an industry, that company would have $100 \%$ market share, and the HHI would equal 10,000 (100^2), indicating a monopoly. Or, if there were thousands of companies competing, each would have nearly $0 \%$ market share, and the HHI would be close to zero, indicating nearly perfect competition. The market is not concentrated if the HHI is lower than 1,000 , medium concentrated is a market, which has HHI between 1,000 and 1,800 and 
concentrated markets are those, which have this HHI higher than 1,800. Considering the VPF market in Serbia, this index is very high, around 2,800 and it indicates very high concentration of the VPF market in Serbia. Two VPFs management companies comprise around $97 \%$ of the market in Serbia, of which the biggest company has a share of $42 \%$ of the VPF market.

For the development of voluntary pension insurance, it is necessary to increase the standard of living of the population, strengthen macro-economic assumptions of development, raise awareness about the necessity of individuals possessing such additional forms of pension insurance, increase the amount of contributions subject to favourable tax treatment, create conditions for the development of collective voluntary pension insurance and so on. For several years now, the citizens of our country have been receiving clear signals that they need additional savings for their secure future. In the future, they will have to decide for one of the following forms of saving for old age, either through traditional banking services, or through the services of life insurance, using the services of voluntary pension insurance and so on. With detailed explanations of the advantages and disadvantages of all the above forms of savings, savings through the voluntary pension system will most certainly be interesting for the citizens of our country (RAKONJAC-ANTIĆ \& RAJIĆ 2010). However, the key elements of the system must be forced: transparency and security of the systems. As already mentioned above, the development of financial markets (primary and secondary) is one of the prerequisites for the development of the voluntary pension insurance (RAKONJAC-ANTIĆ 2012).

However, all of the above prerequisites for the development of voluntary pension insurance are deeply dependent on certain factors. These are primarily the standard of living or level of employment and net income of households. They directly affect the possibility of allocating additional resources for the purpose of this type of insurance. If there are opportunities, market development of voluntary pension insurance is additionally dependent on the state of age and educational structure of the population. For countries such as Serbia, with very low performance of the voluntary pension insurance, it is very important to identify those areas that have a larger number of beneficiaries, or those who have not yet begun to develop this type of insurance and have the conditions for it. Regional analysis of the factors of supplementary pension insurance in this respect is desirable and relies profoundly on the obvious regional differences of each of the individual elements of a given system.

\section{Regional disparities of the voluntary pension-insurance market}

Voluntary pension insurance is poorly developed in Serbia, primarily due to the low living standards in the Republic. At state level, the number of insured persons is 
low, and they are unevenly deployed, especially if we look at the lower spatial units (Fig. 1 and 2).

Figure 1: Number of participants in the VPF, 2013

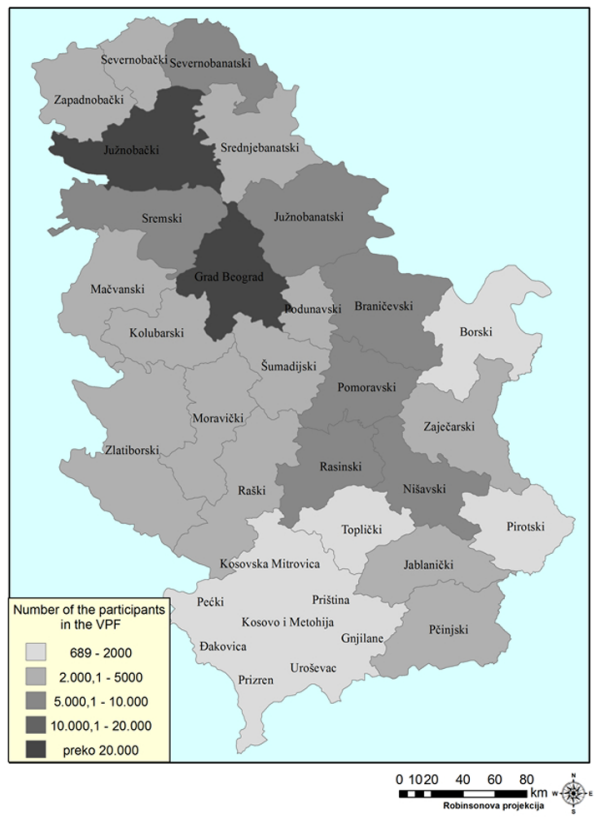

Figure 2: Average accumulated funds per participant, 2013

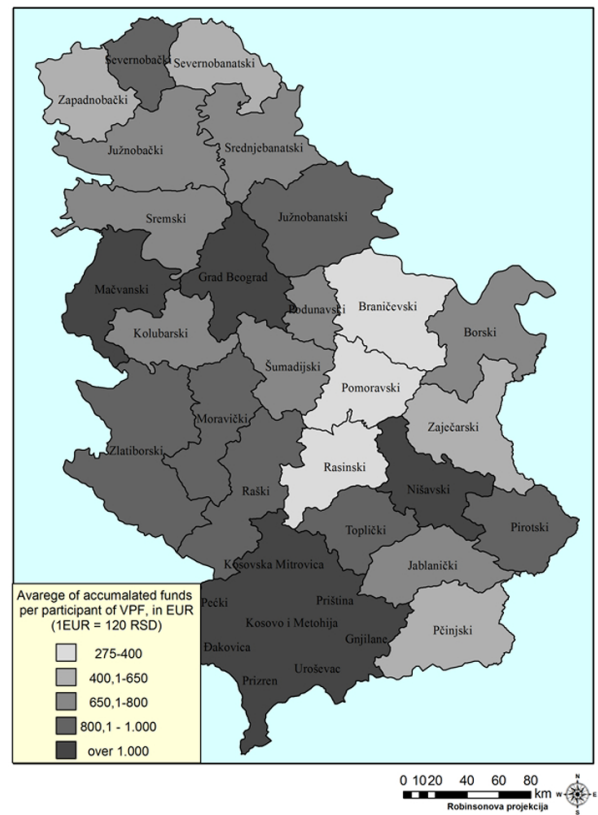

Source: The National Bank of Serbia - Department for Supervision of the Insurance Business, The Department for Supervision over the Activities of Voluntary Pension Funds 2014; Statistical Office of the Republic of Serbia 2014

Regional distribution of VPF participants shows some expected trends: the largest concentration is in Belgrade [Beograd] and the South Bačka District [Južnobački okrug] (Novi Sad), while the remaining regions have less than 10,000 insured (Bor [Borski okug], Pirot [Pirotski okrug] and Toplica [Toplički okrug] Districts have a very small number of insured under 2,000). If this VPI indicator is compared with another indicator - the average amount of contributions per insured, it is possible to establish certain regularities. The Belgrade Region [Grad Beograd] is at the top of the regions with the highest amounts of accumulated funds by the insured, followed by the South Bačka and Nišava [Nišavski okrug] Districts. There are, however, certain deviations, as is the case with Mačva District [Mačvanski okrug] with the highest amount of contributions paid per the insured (Fig. 2), while the number of insured persons in the 
District is under 5,000 (Fig. 1). On the other hand, Braničevo [Braničevski okrug], Pomoravlje [Pomoravski okrug] and Rasina [Rasinski okrug] Districts have the lowest average accumulated funds per insured person, but they have a larger number of participants in the VPF (between 5,000 and 10,000 insured).

The system of voluntary pension insurance depends on a number of factors. Basically, the most important group of factors is that relating to the living standard of the population, and the possibility that people set aside additional funds for this type of insurance (employment/unemployment, net income/earnings). Other factors that shape the VPF market are not decisive, but additionally influence the decision of the population to join the VPF system. These are primarily the age structure of the population, which defines not only their decision to join VPF participants, but also the amount of the dues that these participants have to pay (the older the person, the higher the amount of dues). Another important factor is the educational structure of the population because the level of education and availability of information affects the awareness of people about the need to save for the period when they are no longer of working age.

Regional analysis of the factors of voluntary pension insurance was conducted using GIS, and through SQL analysis of the established database (CODINGTON \& WILSON 1994). In this way it was possible to recognize relations between the above factors, which resulted in the number and spatial distribution of insured in the VPI system. GIS analysis normally allows the interpenetration of queries against the database and visualisation of those areas where there is potential for expansion of specific processes/ phenomena (GRIMSHAw 2000).

If we take the standard of living, indicated by the number of employees and the level of the average net earning per employee, it can be concluded that there is a certain regularity in the concentration of the largest number of employees and the highest salaries in Serbia. (These are the most developed regions such as the Belgrade Region and the South Bačka District).

However, if we compare the current number of VPI participants with one of these factors, for example the average net earnings per employee, and make a request to select those areas where the level of earnings is relatively high (above 40,000 Dinars) and where there is a small number of insured in the VPI system (less than 2,000), we obtain very interesting results (Fig. 3). Only one region that meets the established criteria is extracted, and this is the Bor District. It is an area of eastern Serbia, which is relatively sparsely populated, with a low birth rate and a negative migration balance. But the high average net profits per employee are the key factor why the Bor District is interesting for VPI in spite of the negative trends related to other factors. Such earnings are derived from the fact that the majority of the working age population is employed in a public company in the sector of electric power generation, the hydropower plants "Đerdap I" and "Đerdap II", in which the average net salary per employee is above 
the national average. The current small number of VPI participants may be a result of the people employed in the aforementioned public company not being the interested in paying their own voluntary pension insurance, or the lack of interest of the part of the company to pay its employees a voluntary pension insurance up to the non-taxable amount of 5,420 Dinars. While it would appear that there is enough space for VPImarket expansion in this district, if we take into account the negative demographic trends, the future of the VPI market in the Bor District is not great (unfavourable age structure of the population in terms of the development of voluntary pension insurance). This shows that several factors must be considered with the identification of potential areas for VPI growth.

Figure 3: Areas with the largest growth potential in terms of voluntary pension insurance, viewed from the perspective of the influence of earnings per employee, 2013

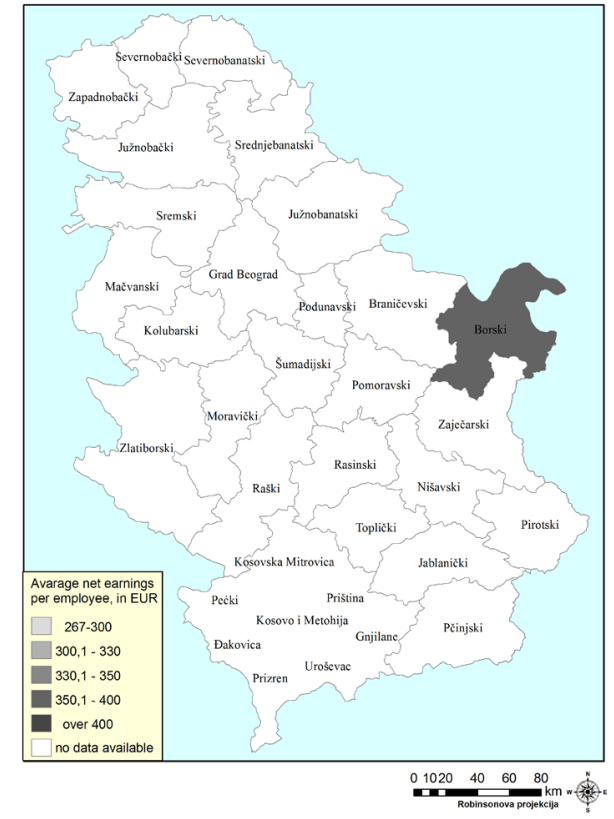

Sources: The National Bank of Serbia - Department for Supervision of the Insurance Business, The Department for Supervision over the Activities of Voluntary Pension Funds 2014; Statistical Office of the Republic of Serbia 2014

The population with a higher level of education (college and university degree) should have more participation in the VPI system, so that it is able to perceive the benefits of this type of pension insurance sooner than the population with a lower 
level of education. Its combination with the factor of living standard reveals the real potentials of certain areas in Serbia.

Figure 4: Areas with the highest potential for voluntary pension-insurance growth from the perspective of the influence of the education level of the population, 2013

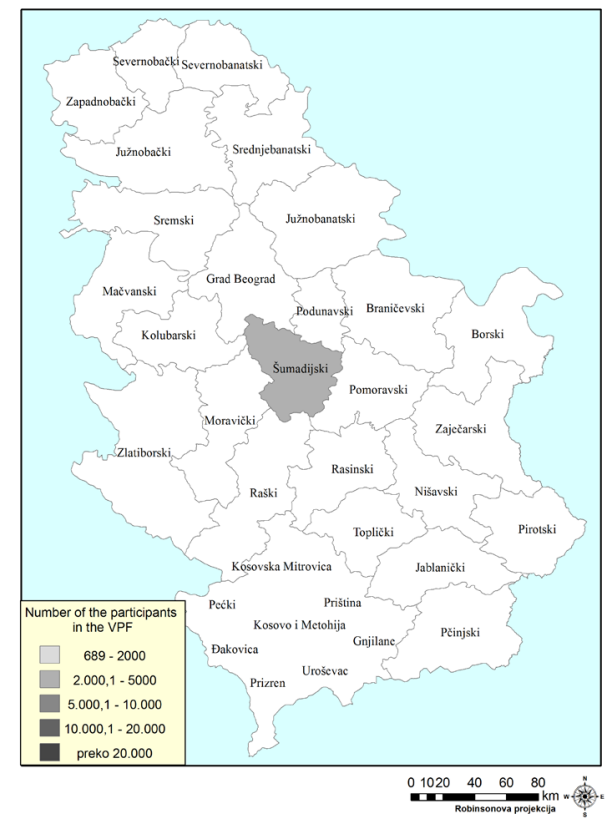

Sources: The National Bank of Serbia - Department for Supervision of the Insurance Business, The Department for Supervision over the Activities of Voluntary Pension Funds 2014; Statistical Office of the Republic of Serbia 2014

If we assume that the number of employees is one of the reliable indicators of the level of living standards (number of employees higher than 50,000) and we cross it with the level of education of the population (the share of highly educated population in the total population older than 15 years, higher than $12 \%$ ), this identifies regions that are interesting in terms of VPI-market expansion. In order to investigate, which of these areas are currently not saturated by this type of insurance, the synthesizing query included the constraint that the isolated regions must have fewer than 5,000 VPI insured (Fig. 4).

The Šumadija District [Šumadijski okrug] has the strongest potential for VPImarket expansion in this analysis because it has a relatively favourable educational 
structure, since Kragujevac is a university centre (about $15 \%$ of highly educated population older than 15). The Šumadija District owes its relatively solid standard of living compared to the rest of Central Serbia to the automotive industry in the form of the "Fiat Serbia" production facility and its sub-contractors located there (over 50,000 employees). However, this district has a relatively small number of VPF beneficiaries, which is most probably due to the difficult economic situation over the past two decades (before the investment of Fiat).

The age structure of the population is one of the criteria that the voluntary pension funds management companies always take into account when performing market segmentation.

Previous experience and practice in this area of pension insurance have shown that the required minimum limit of investment of the funds of the insured is 10-15 years so that, based on the growth of the investment unit and fees paid, the conditions are created for the payment of a satisfactory pension. Therefore, the age group of the population of interest for the development of voluntary pension insurance are those between the ages of 20 and 40 .

GIS analysis of the age structure of the population of Serbia determined the share of those between 20 and 40 years of age in the total population by districts, and then, SQL queries were used to separate those areas that have above $26 \%$ share of the specified age group. This factor was crossed with one of the most commonly used indicators of VPF-market development, the proportion of insured persons in the total population by districts. Thus, the synthetic queries were used to single out those districts that have less than $2 \%$ of insured persons in the total population and a higher share of the population aged between 20 and 40 (Fig. 5). The districts that were singled out are potential markets for VPF growth due to their age structure: Pčinja [Pčinjski okrug] and Raška [Raški okrug] Districts have higher birth rates and population growth and therefore younger population, while other districts (Šumadija, Srem [Sremski okrug] and North Bačka [Severnobački okrug]) have a relatively favourable age structure because they are migration destinations, university centres, etc. However, to make these areas really taken into consideration as potentially interesting, it is necessary to introduce additional analysis in terms of the influence of other factors, notably the level of living standard. 
Figure 5: Areas with the highest potential for voluntary pension-insurance growth from the perspective of the influence of the age of the population, 2013

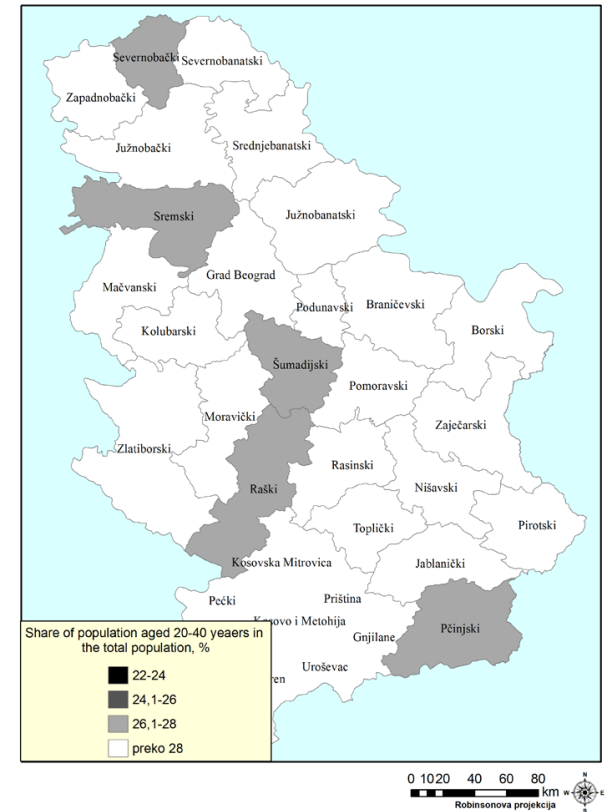

Sources: The National Bank of Serbia - Department for Supervision of the Insurance Business, The Department for Supervision over the Activities of Voluntary Pension Funds 2014; Statistical Office of the Republic of Serbia 2014

\section{Conclusions}

Voluntary pension insurance in Serbia is not developed and is, in most cases, an additional form of pension (pension remuneration) for the participants in the system. There is progress in the development of the pension system in Serbia, but this is not so significant to influence the development of the overall pension system to a greater extent. In the first quarter of 2014, there were four voluntary pension-insurance funds in the voluntary pension-insurance market. A total of 185,793 insured who concluded 250,353 contracts on voluntary pension insurance participated in the system. However, since Serbia is a country with very large regional differences in terms of social and economic indicators, it inevitably reflected on the state of the regional voluntary pension insurance market in Serbia. There are large differences, with concentrations mainly in major urban centres and economic regions, Belgrade and the South Bačka District. 
For the development of voluntary pension insurance it is necessary to increase the standard of living, stabilise the macro-economic assumptions and the financial system, to educate the population about the necessity of using this type of insurance, develop financial markets, strengthen tax relief, and focus on strengthening the security system of voluntary pension insurance. However, another factor greatly contributing to its growth is awareness of the insurance companies of the potential areas where to spread this kind of insurance. To this end, different regional market analyses are performed using standard statistical methods and models, as well as newer, more sophisticated techniques (GIS). GIS has been used extensively over the last 20 to 30 years as an advanced and sophisticated technique of spatial analysis of the voluntary pension-insurance market. The voluntary pension-funds management companies in the developed systems are more than ever reliant on analyses as a strategic technology that enables a faster and better decision-making.

In addition to the analysis and visualisation of the development indicators for this market at regional level, the analysis of the voluntary pension-insurance market in Serbia also included the analysis and visualisation of the key factors for the development for VPF. The market was profiled through SQL queries, according to the criteria of living standards (number of employees and net average earnings), educational and age structure of the population. Depending on the influence of the dominant factors, the analysis has highlighted areas where the level of living standards, higher education structure or age structure were more favourable, with a relatively small number of VPF participants.

In addition to visualising the regional distribution of current VPF participants, we have also provided a regional analysis of the territory of Serbia from the perspective of the potential that the population has in this regard. This is particularly important for decision making and business policy of voluntary pension-funds management companies, but also for the development of this form of pension insurance in the context of a future reform of pension insurance in Serbia.

\section{References}

Codington S., Wilson T.D. (1994), Information Systems Strategies in the UK Insurance Industry. In: International Journal of Information Management, 14, 3, pp. 188-203.

Eichhorst W., Gerard M., Kendzia M., Mayrhuber C., Nielsen C., Runstler G., Url T. (2011), Pension systems in the EU-contingent liabilities and assets in the public and private sector. In: Policy department a: economic and scientific policy, pp. 120-127. Brussels, Directorate general for internal policies.

Francica J.R. (1993), Insurance. In: Castle H.G (ed.), Profiting from Geographic Information System, pp. 75-84. Fort Colins (CO), GIS World Books.

Francica J.R. (1994), Insurance Application. In: International GIS Sourcebook, pp. 329-343. Fort Colins (CO), GIS World Books. 
Grimshaw J.D. (2000), Bringing Geographical Information Systems into Business, Second Edition. New York, Wiley.

Hrvatska Agencija za Nadzor Financisskin Usluga (HANFA) <www.hanfa.hr>

Kočović J., RAKonjac-Antić T., Jovović M. (2011), Mogućnosti i ograničenja razvoja dobrovoljnog penzijskog osiguranja u Srbiji. In: Časopis za teoriju i praksu radnog i socijalnog prava „Radno i socijalno pravo", Consultation organised by the Association for insurance law of Serbia and law on social security, Belgrade, vol.,1, pp. 1-11.

Kočović J., Šulejí́ P., Rakonjac-Antić T. (2010), Osiguranje. Beograd, Publishing Centre, Faculty of Economics.

Le Blanc J. (2011), The third pillar in Europe: institutional factors and individual decisions (= Discussion paper series 1: Economic Studies, 09/2011, 36). Frankfurt am Main, Deutsche Bundesbank Eurosystem.

Longley A.P., Goodchild F.M., MaguiRe J.D., Rhind W.D. (2005), Geographical Information Systems and Science, Second Edition. New York, Wiley.

Longley A.P., Graham C. (1995), GIS for Business and Service Planning. New York, Wiley.

MANić E. (2010), Geografski informacioni sistemi i prostorne analize u trgovini. Belgrade, Publishing Centre, Faculty of Economics.

Narodna Banka SRbIJE <www.nbs.rs >

Rakonjac-Antić T. (2012), Penzijsko i zdravstveno osiguranje. Belgrade, Publishing Centre, Faculty of Economics.

RakonjaC-Antić T., RaJIĆ V. (2010), Analiza tržišta penzijskog i invalidskog osiguranja u Srbiji. In: Kočović J., Hanić H (eds.),, Osmi medunarodni simpozijum iz osiguranja „Problemi poslovanja osiguravajucih kompanija u uslovima krize”, pp. 109-126. Zlatibor, Insurance and Actuary Institute.

Statistical Office of the Republic of Serbia (ed.) (2014), Municipalities and Regions of the Republic of Serbia.

The Law on Voluntary Pension Funds and Pension Plans, 85/2005 and 31/2011

The National Bank of Serbia - Department for Supervision of the Insurance Business, The Department for Supervision over the Activities of Voluntary Pension Funds (ed.) (2014), The Statistical Annex.

The NBS Reports on the Voluntary Pension Funds Sector in Serbia for Q4 2007, 2008, 2009, 2010, 2011, 2012, 2013, and Q1 of 2014 